\title{
Proposta de metodologia de planejamento estratégico para pequenas propriedades rurais de base familiar
}

\author{
Lorimar Francisco Munaretto ${ }^{1}$ \\ Sabrine Dellarmelin ${ }^{2}$ \\ Régis Bortolin Rosin ${ }^{3}$
}

\begin{abstract}
Resumo: 0 modelo de gestão rural familiar seguido por diversas propriedades gera preocupações por diferentes motivos, entre os quais estão a falta de controle de custos de produção, a carência de inserção em tecnologia e informação, a falta de agilidade na tomada de decisões diante de situações complexas e, especialmente, a falta de planejamento estratégico. Os modelos tradicionais de planejamento estratégico utilizados possuem abordagem de uso focada em empresas do setor público e/ou privado. A literatura apresenta poucos estudos sobre os modelos de planejamento estratégico para serem utilizados nas pequenas propriedades rurais de base familiar. O presente estudo teve por objetivos: i) desenvolver uma metodologia de planejamento estratégico para pequenas propriedades rurais de base familiar e ii) implementar a metodologia proposta de planejamento estratégico em uma pequena propriedade de base familiar. A partir dos principais modelos de planejamento estratégico existentes na literatura, foi proposta uma metodologia para atender às condições das pequenas propriedades rurais de base familiar. Com a metodologia adequada a uma pequena propriedade rural, é possível conhecê-la como um todo, seus pontos fortes e fracos.
\end{abstract}

Palavras-chave: Planejamento estratégico. Base familiar. Metodologia. Pequenas propriedades.

Abstract: The family farm management model followed by several properties raises concerns for different reasons. The lack of control of production costs, the lack of integration technology and information, the lack of agility in decision-making on complex situations and, especially, the lack of strategic planning. Traditional models of strategic planning used have use of approach focused on companies in the public and / or private. The literature contains few studies on strategic planning models to be used in small farms and family based. This study aimed to: i) develop a strategic planning methodology for small farms and family-based and ii) implement the strategic planning methodology proposed, in a small family-based property. From the main models of strategic planning, in the literature, a method was proposed to meet the conditions for small farms and family based. With the appropriate methodology to a property, you can know the property as a whole, strengths and weaknesses.

Keywords: Strategic planning. Family-based. Methodology. Smallholdings.

\footnotetext{
${ }^{1}$ Doutor em Administração. Professor da Universidade Federal de Santa Maria (UFSM) - Campus de Frederico Westphalen (RS). franciscomunaretto@gmail.com

${ }^{2}$ Engenheira Agrônoma. sabrinedellarmelin@hotmail.com

${ }^{3}$ Engenheiro Agrônomo. regisbortolinirosin@hotmail.com
} 


\section{Introdução}

O modelo de gestão rural familiar seguido hoje por diversas propriedades gera preocupações por diferentes motivos. O modo de administração, a falta de controle de custos de produção, a carência de inserção em tecnologia e informação, a falta de agilidade na tomada de decisões diante de situações complexas e, especialmente, a falta de planejamento estratégico estão entre eles.

A propriedade rural, atualmente, não pode ser mais abordada como no passado, pois a realidade é outra, o mercado está mais competitivo e a margem de lucro é reduzida; a mão de obra da família que conduz a propriedade está gradativamente reduzindo. Um dos problemas é a falta de conhecimento da realidade em que estão inseridos, como mercado, recursos humanos, alternativas financeiras, custos de produção, entre outros. A elaboração de uma estratégia integra as principais metas que se deseja alcançar, onde a tática auxilia na tomada de decisões, estabelecendo quais serão os caminhos, os programas de ação que devem ser seguidos para alcançar os objetivos e/ou resultados (BRUN, 2013).

A maioria dos produtores rurais administram e tomam as decisões apenas por conhecimentos próprios, adquiridos anteriormente na administração de sua propriedade. Com base nisso, ressalta-se que é de grande importância para qualquer empreendimento, inclusive o agropecuário, desenvolver um planejamento estratégico das atividades que são realizadas. A elaboração de um plano com estratégias visa estabelecer quais serão os caminhos a serem seguidos para alcançar os alvos (ANTUNES, 1999).

A concepção e a implementação do planejamento no setor rural representam um grande desafio, tendo em vista que as propriedades desse setor estão sujeitas a um elevado número de variáveis, como a dependência de recursos naturais, a sazonalidade de mercado, a perecibilidade dos produtos (tempo de maturação), o ciclo biológico de vegetais e animais (VILCKAS, 2004).

O principal desafio de tornar a propriedade rural familiar mais competitiva está no desenvolvimento de informação, capaz de facultar processos de gestão, organização da produção, promoção da diferenciação de produtos, visando à criação de oportunidades na 
inserção competitiva dos produtores rurais com economia familiar. Todo esse processo é bastante demorado, pois a agricultura familiar tem muitos limitantes na questão relativa aos recursos financeiros.

A adoção do planejamento estratégico proporciona o diagnóstico e a análise do ambiente, permitindo ao administrador uma melhor leitura do futuro de suas atividades. Contudo, as dificuldades para a sua adoção aumentam nas empresas rurais, com a elevação dos riscos e incertezas, bem como a convivência com mudanças repentinas (JANK; LOPES, 1992; NEVES, 1996).

Os modelos tradicionais de planejamento estratégico utilizados possuem abordagem de uso em empresas do setor público e/ou privado. São poucos os estudos envolvendo os modelos de planejamento estratégico adequados ao uso das pequenas propriedades rurais.

Tendo em vista contribuir com os estudos existentes na área, o presente trabalho tem por objetivos: i) desenvolver uma metodologia de planejamento estratégico para pequenas propriedades rurais de base familiar e ii) implementar a metodologia de planejamento estratégico proposta em uma pequena propriedade de base familiar.

Há necessidade de ampliar a adoção das técnicas de gestão por parte dos empresários familiares rurais, devendo-se respeitar a dinâmica específica destes produtores ao fazer a transposição dos conceitos de técnicas administrativas do setor urbano para este segmento (RIBEIRO, 1995). Assim, a partir dos principais modelos de planejamento estratégico existentes na literatura, será proposta uma metodologia para atender às condições das pequenas propriedades rurais de base familiar.

O estudo, além do capítulo introdutório, apresenta, no segundo capítulo, a revisão teórica, com a proposta teórica de modelo de planejamento estratégico para as pequenas propriedades rurais de base familiar; no terceiro capítulo, fala-se sobre o delineamento metodológico do estudo; no quarto capítulo, realiza-se a aplicação prática da metodologia em uma pequena propriedade, e, por fim, apresentam-se as conclusões e a bibliografia utilizada no estudo. 


\section{Revisão teórica}

A revisão teórica está estruturada nas seguintes seções: na primeira seção discorre-se sobre planejamento; na segunda seção, apresentam-se os tipos de planejamento, e, após, na terceira seção, descrevem-se as principais metodologias de planejamento estratégico; na quarta seção, apresenta-se uma proposta de roteiro de planejamento estratégico para pequenas propriedades rurais, e, por fim, define-se pequena propriedade de base familiar.

\subsection{Planejamento}

O setor agropecuário é caracterizado como uma atividade de longo prazo, com investimentos elevados, onde o planejamento é fundamental. O planejamento estratégico é uma importante ferramenta de gestão para as organizações na atualidade, tanto para empresas como em empreendimentos rurais.

O planejamento é constituído de importantes funções administrativas, sendo que é através dele que o gestor e sua equipe (que é o caso da agricultura familiar, composta pelos membros da própria família) formam os parâmetros que vão conduzir a propriedade ou empresa à liderança, assim como ao controle das atividades. O objetivo do planejamento é fornecer aos gestores e suas equipes uma ferramenta que os abasteça de informações para a tomada de decisão, ajudando-os a atuar de forma eficaz, antecipando-se às mudanças que ocorrem no mercado em que atuam.

Saber usar as ferramentas do planejamento de forma coerente, amoldar-se à realidade da empresa e às suas obrigações, pode ser, então, uma excelente arma competitiva. Para utilizá-la eficientemente, é importante que os gestores reconheçam bem cada um dos elementos do planejamento e suas funções, assim como as alterações que estão ocorrendo no contexto competitivo, as quais estão influenciando na própria prática do planejamento e lançando alguns desafios para a gestão nas empresas. 
O maior desafio da pequena propriedade rural familiar está relacionado ao processo de agregação de valor, em virtude da pequena escala de produção e de problemas de gestão por falta de conhecimentos de planejamento. Toda problemática enfrentada pela pequena propriedade de base familiar pode ser solucionada com um planejamento elaborado dentro das exigências e características desse setor.

\subsection{Tipos de planejamento}

O planejamento é composto por três tipos e níveis, sendo eles o planejamento estratégico, o tático (gerencial) e o operacional, como demonstra-se na Figura 1.

\section{Figura 1 - Níveis de planejamento}

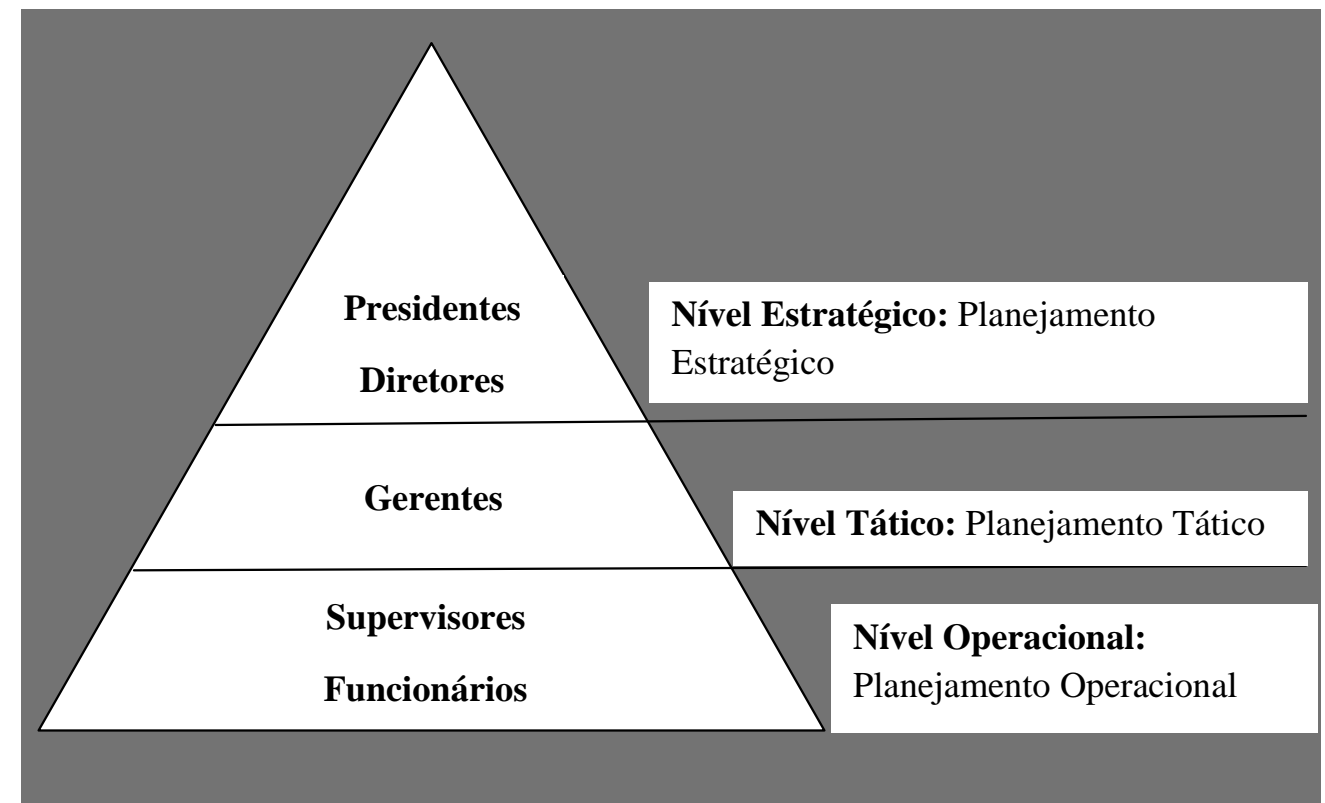

Fonte: Adaptado de Santos (2010).

Dentro das organizações, nota-se que esses três níveis (estratégico, tático e operacional) têm sua parcela de importância, pois um nível complementa as ações dos demais níveis no interior da empresa, ou seja, um nível necessita do outro para que as atividades consigam ser realizadas de forma satisfatória. 


\subsubsection{Planejamento estratégico}

Planejamento estratégico é um instrumento administrativo que procura uma organização das ideias do planejador, procurando identificar o caminho que deve ser seguido pela empresa. Após o arranjo dessas ideias, deve haver um ordenamento das ações, ou seja, a execução do plano estratégico para que a empresa alcance seus objetivos sem desperdício de recursos.

Acredita-se que o planejamento estratégico não deve ser elaborado em pequenas empresas, possivelmente devido à sua complicação. No entanto, essa técnica pode ser desenvolvida também em empresas de pequeno porte, porém, neste caso, o processo deve ser simplificado (ALMEIDA, 2001).

Em uma pequena propriedade rural, os planos estratégicos estão ligados prioritariamente à aquisição de novas áreas para plantio, relacionados às mudanças da matriz produtiva na pequena propriedade, com novos investimentos de longo prazo.

\subsubsection{Planejamento tático}

Por meio do nível tático, o planejamento ocorre a médio prazo. 0 nível tático é o conjunto de tomada de decisões que envolvem ações restritas, de prazos mais curtos, com áreas menos amplas e níveis mais inferiores de hierarquia da organização. Sendo assim, observa-se que o planejamento tático se relaciona com o planejamento estratégico, sendo que o que diferencia um do outro é a questão de decisão no interior da empresa (CHIAVENATO, 1994, p. 186).

O planejamento tático é o intermediário do planejamento estratégico e do planejamento operacional. Este nível possui o foco nas percepções externas e internas, no mesmo período de tempo, sendo que os membros do nível tático devem saber o que acontece no ambiente externo para que possa agir de forma viável em sua estratégia no interior da empresa (TAJRA, 2006, p. 55). Na pequena propriedade rural, o nível tático ou 
gerencial ocorre por meio dos planos financeiros, plano da produção das culturas, entre outros.

\subsubsection{Planejamento operacional}

O nível operacional refere-se aos encarregados de executarem as atividades propostas no interior da organização. Neste nível, o planejamento é realizado em um curto período de tempo. O objetivo é fazer acontecer, realizando de perto um acompanhamento das operações que geram o produto final, o serviço, o trabalho da empresa. Conclui-se, então, que este planejamento é constituído de todos os planos de ações que fazem parte do planejamento operacional de uma empresa (TAJRA, 2006, p. 55).

No planejamento, impõe-se definir o que se deve fazer, quais os objetivos a serem alcançados. O planejamento estratégico deve ser empregado para definição de um objetivo em longo prazo. No planejamento operacional, os agricultores devem estar ligados ao uso da terra, como plantar, em quais épocas, quantidade, programa de trabalho, o que fazer durante os dias, dentre outras atividades (AMARAL et al., 2010).

2.3 Principais metodologias de planejamento estratégico

Diversas propostas de metodologias de planejamento estratégico, utilizadas pelas organizações em geral, são apresentadas na literatura. A figura 2 apresenta as etapas que compõem processo de planejamento estratégico. 
Figura 2 - Principais etapas que compõem o processo de planejamento estratégico de diversos autores.

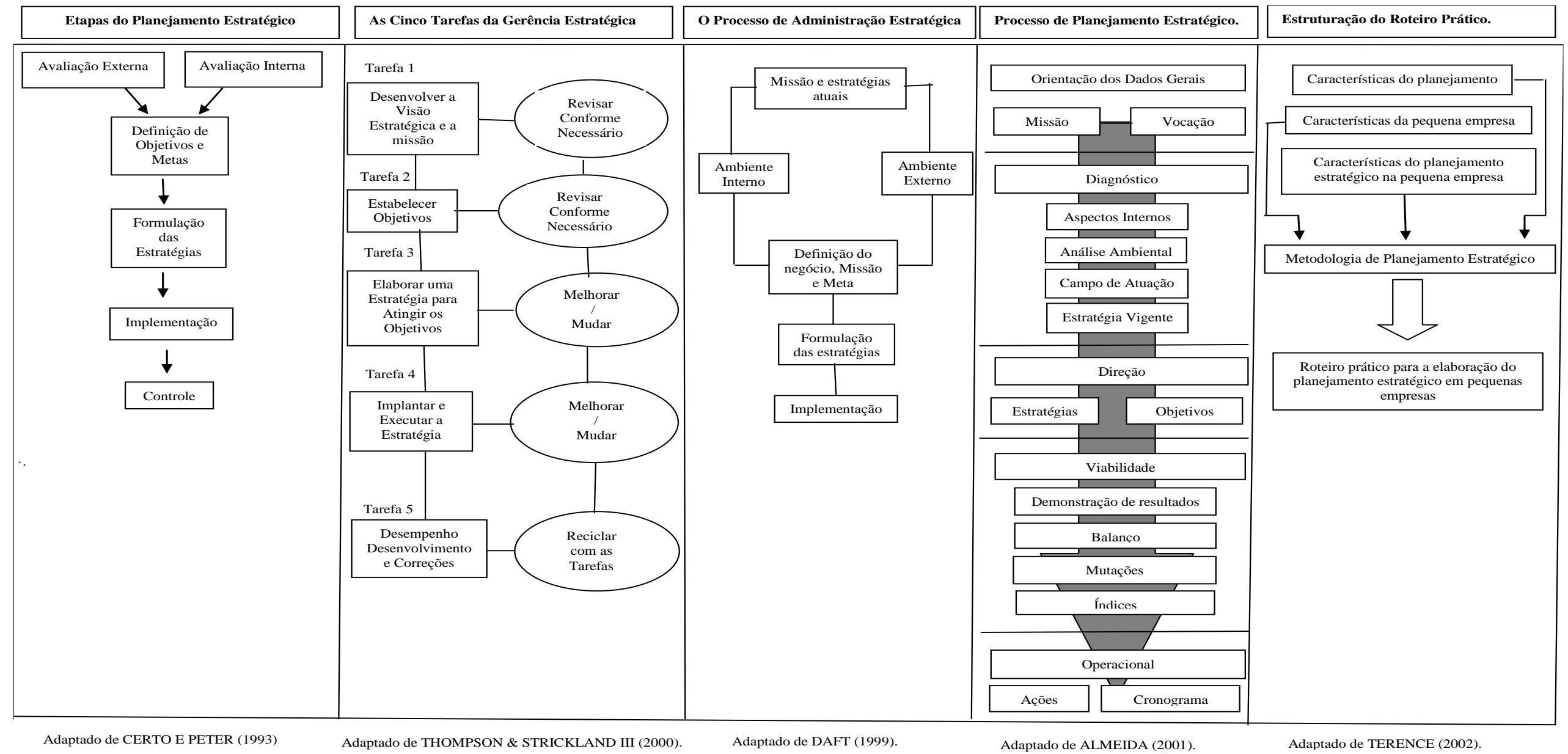

Fonte: Elaborado pelos autores.

COLÓQUIO - Revista do Desenvolvimento Regional - Faccat - Taquara/RS - v. 16, n. 1, jan./jun. 2019 
As pequenas propriedades rurais de base familiar possuem características intrínsecas, entre as quais a gerência realizada pelos próprios membros da família, a terra como principal - se não o único - fator de produção, relação indissociável entre patrimônio da propriedade e proprietários, diversificação de atividades agrícolas e agropecuárias, dentre outras. Nesta perspectiva, torna-se importante a elaboração de uma metodologia de planejamento estratégico, adequando-se às realidades das pequenas propriedades rurais de base familiar.

Um dos desafios que se coloca para a administração rural é encontrar as melhores combinações de meios de produção necessários ao progresso técnico da agricultura, melhorando a sua produção e a sua eficiência, a partir da organização dos fatores produtivos de que dispõe o produtor (SALDANHA; SOARES JÚNIOR; DEL GROSSI, 2002).

\subsection{Proposta de roteiro de planejamento estratégico para pequenas propriedades rurais}

Na sequência, apresentam-se as etapas da proposta do planejamento estratégico para pequenas propriedades rurais (Figura 3). O modelo proposto foi constituído a partir das abordagens teóricas apresentadas pelos autores Almeida (2001), Terrence (2002), Certo e Peter (1993), Thompson J4 e Strickland III (2000) e Daft (1999).

Figura 3 - Etapas do processo de planejamento estratégico

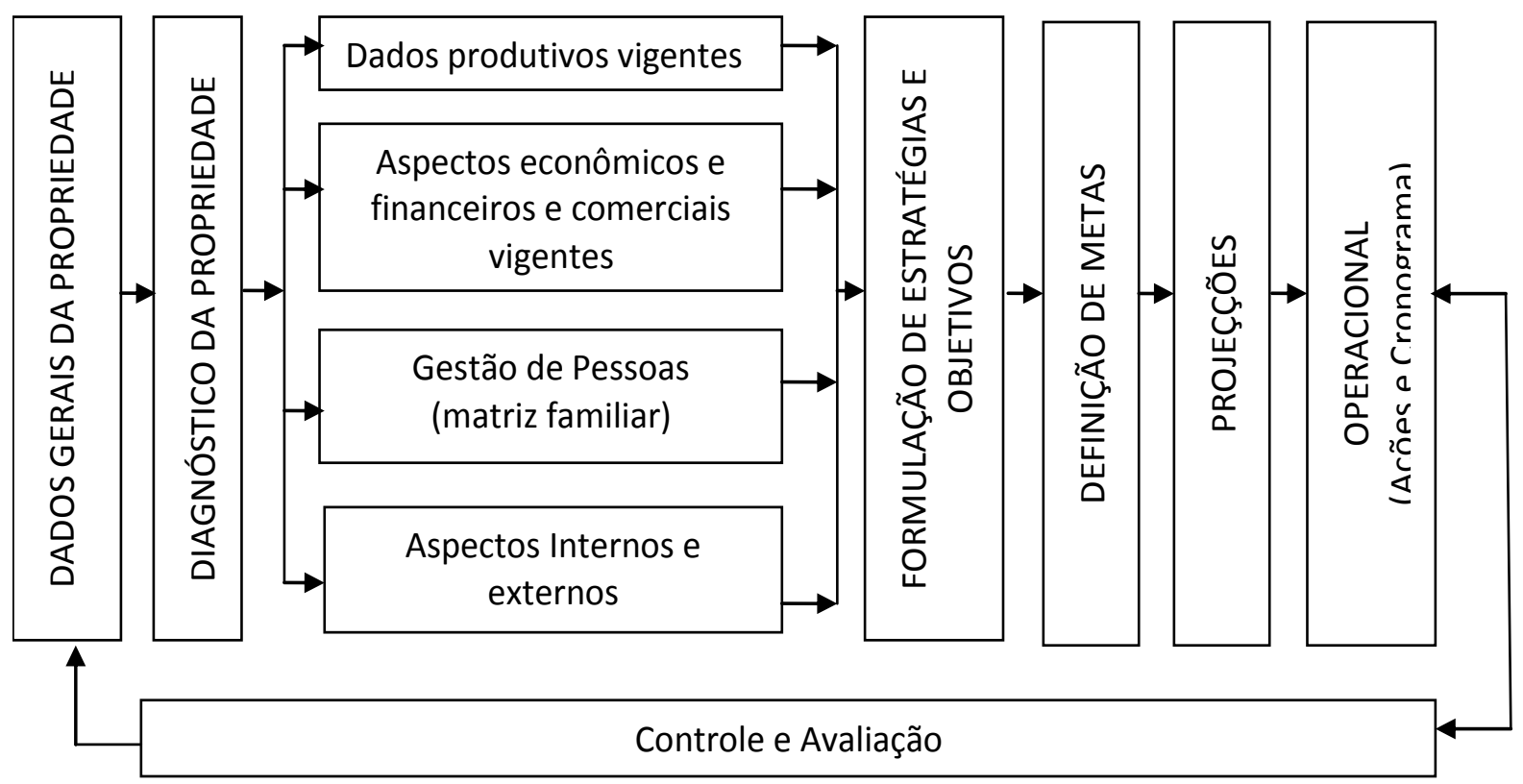

Fonte: Elaborado pelos autores.

COLóQUIO - Revista do Desenvolvimento Regional - Faccat - Taquara/RS - v. 16, n. 1, jan./jun. 2019 


\subsubsection{Descrição da proposta de metodologia de planejamento estratégico da propriedade}

Por meio do quadro 1, apresentam-se as sete etapas que compõem a proposta de metodologia do planejamento estratégico, a ser utilizada em pequenas propriedades rurais de base familiar.

\section{Quadro 1 - Etapas que compõem a metodologia de planejamento estratégico}

\begin{tabular}{|c|c|}
\hline \multirow[b]{2}{*}{$\begin{array}{l}-1 \\
\mathbb{8} \\
\stackrel{0}{0} \\
\stackrel{D}{0}\end{array}$} & dos gerais da $p$ \\
\hline & $\begin{array}{l}\text { Nesta etapa, apresentam-se os dados gerais da propriedade, considerando os dados da formação } \\
\text { inicial da propriedade até o momento atual. }\end{array}$ \\
\hline $\begin{array}{l}N \\
\mathbb{2} \\
\frac{0}{\pi} \\
\mathbb{4}\end{array}$ & $\begin{array}{l}\text { Diagnóstico da propriedade. } \\
\text { No diagnóstico, em relação à propriedade, deve-se responder sobre: Quem somos? O que fazemos? } \\
\text { Por que fazemos? Como se está? Devem ser definidas a missão (razão da existência da propriedade) e } \\
\text { a visão (como a propriedade quer ser vista), além dos princípios norteadores dos proprietários. Esta } \\
\text { etapa é composta pelos seguintes itens: a) dados produtivos da propriedade e seu uso; b) análise dos } \\
\text { aspectos econômicos da propriedade; c) gestão de pessoas; e d) análise dos aspectos internos e } \\
\text { externos por meio da matriz SWOT. } \\
\text { a) Dados produtivos da propriedade e seu uso } \\
\text { Devem-se descrever os dados produtivos da propriedade, a utilização das suas áreas em relação às } \\
\text { atividades desenvolvidas. É importante que seja apresentado (elaborado) um mapa da propriedade } \\
\text { com a distribuição das áreas utilizadas. As características ambientais da propriedade devem ser } \\
\text { colocadas nessa parte. } \\
\text { b) Análise dos aspectos econômicos e financeiros } \\
\text { Deve-se realizar o levantamento do conjunto de bens, direitos e obrigações da propriedade. No que } \\
\text { se refere aos aspectos econômicos, devem ser identificados os valores das receitas obtidas na } \\
\text { propriedade, suas fontes e representatividade em relação à receita total. Também devem ser } \\
\text { identificados os valores das despesas, dos custos de produção nas atividades, o fluxo de caixa, etc. } \\
\text { c) Gestão de pessoas (matriz familiar) } \\
\text { As atribuições e responsabilidades de cada membro da família nas atividades realizadas na } \\
\text { propriedade devem ser descritas, assim como verificado o processo de sucessão na propriedade. } \\
\text { d) Análise dos ambientes interno e externo. } \\
\text { Nesta etapa, busca-se descrever os pontos fortes e fracos em relação à propriedade e às ameaças e } \\
\text { oportunidades em relação ao ambiente externo da propriedade. O objetivo a posteriori desta análise } \\
\text { é o de eliminar os pontos fracos e priorizar os pontos fortes em relação aos aspectos internos da } \\
\text { propriedade, com o aproveitamento das oportunidades no ambiente externo da propriedade. }\end{array}$ \\
\hline & \\
\hline & $\begin{array}{l}\text { Após análise do diagnóstico, será possível definir as estratégias e os objetivos da propriedade. As } \\
\text { estratégias envolvem o caminho que deve ser seguido para alcançar o(s) objetivo(s) desejado(s) } \\
\text { (ALMEIDA, 2010). As principais estratégias gerais em uma pequena propriedade rural são as de } \\
\text { sobrevivência, crescimento, manutenção e desenvolvimento. Ex. a) Ampliação ou diminuição da área } \\
\text { para cultivo agrícola; b) renovação de equipamentos, mediante financiamentos ou não; b) aumento } \\
\text { da atividade pecuária, etc. Os objetivos decorrem da formulação das estratégias gerais. }\end{array}$ \\
\hline
\end{tabular}

(Continua) 


\begin{tabular}{|c|c|c|}
\hline \multirow{2}{*}{ 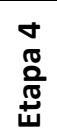 } & \multicolumn{2}{|l|}{ Definição das metas } \\
\hline & \multicolumn{2}{|c|}{$\begin{array}{l}\text { Uma meta se constitui pela quantificação e prazo de realização dos objetivos. Ex. aumentar o rebanho } \\
\text { bovino em } 20 \% \text { até no ano de X4. }\end{array}$} \\
\hline \multirow[b]{2}{*}{ 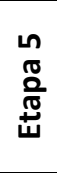 } & \multicolumn{2}{|c|}{ Projeções financeiras - criação de controles } \\
\hline & \multicolumn{2}{|c|}{$\begin{array}{l}\text { Após a definição das estratégias, dos objetivos e metas, será possível apresentar as projeções de } \\
\text { balanço patrimonial, resultados das atividades da propriedade, bem como os fluxos de caixas, com a } \\
\text { integração dos valores decorrentes das metas a serem atingidas. }\end{array}$} \\
\hline \multirow{9}{*}{ 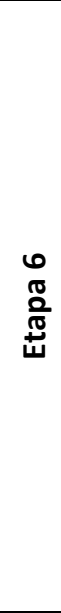 } & \multicolumn{2}{|c|}{$\begin{array}{l}\text { Implementação das ações e cronograma } \\
\text { Por meio dos planos de ações, que podem ser distribuídos aos membros da família, será possível } \\
\text { atribuir responsabilidades em relação às ações e metas operacionais do planejamento. Nesta } \\
\text { perspectiva, cada estratégia, com o(s) objetivo(s), ações e metas, pode ser descrita, como } \\
\text { apresentado a seguir. }\end{array}$} \\
\hline & \multicolumn{2}{|r|}{ Plano de Ação } \\
\hline & Estratégia: & \\
\hline & Objetivo: & \\
\hline & Por quê: & \\
\hline & Como fazer: & \\
\hline & Quem (responsável): & \\
\hline & Quando (prazo): & Início: \\
\hline & Quanto (custo estimado) $\mathrm{R} \$$ : & \\
\hline & \multicolumn{2}{|l|}{ Controle e avaliação } \\
\hline 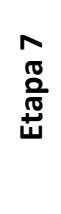 & \multicolumn{2}{|c|}{$\begin{array}{l}\text { Após a elaboração dos planos de ações, com as metas e cronograma, gradativamente, conforme as } \\
\text { ações forem sendo realizadas, será necessário realizar o controle e avaliação das atividades, tendo em } \\
\text { vista verificar os níveis de eficiência e eficácia das estratégias. O controle e a avaliação do plano, em } \\
\text { comparação ao que está acontecendo, devem ser seguidos de uma ação corretiva imediata, em } \\
\text { tempo real, a fim de garantir os resultados esperados. }\end{array}$} \\
\hline
\end{tabular}

Fonte: Elaborado pelos autores.

2.5 Pequena propriedade rural de base familiar

A Constituição Federal de 1988, em seu Artigo 5ำ, Inciso XXVI, ressalta que se define a propriedade rural como aquela cujo trabalho é desenvolvido pela família. $\mathrm{O}$ art. 4으 da Lei 4504/64, (Estatuto da Terra) estabelece como propriedade familiar rural:

[...] o imóvel rural que, direta e pessoalmente explorado pelo agricultor e sua família, Ihes absorva toda a força de trabalho, garantindo-lhes a subsistência e o progresso social e econômico, com área máxima fixada para cada região e tipo de exploração, e eventualmente trabalho com a ajuda de terceiros.

A expressão "agricultura familiar" é recente no Brasil, configurada em documentos oficiais com denominações de "agricultura de baixa renda", "pequena produção" ou "agricultura de subsistência" (ABRAMOVAY, 1997). A agricultura familiar pode ser entendida com base no tamanho da propriedade, pois utiliza basicamente mão de obra familiar, 
apresenta diversidade de produção e prioriza o autoabastecimento com a comercialização do excedente (CALLADO; ALBUQUERQUE; SILVA, 2007).

São apresentadas seis características básicas que definem agricultura familiar (CALLADO; ALBUQUERQUE; SILVA, 2007), sendo elas: a) a gestão é feita pelos proprietários;

b) os responsáveis pelo empreendimento estão ligados entre si por laços de parentesco; c) o trabalho é fundamentalmente familiar; d) o capital pertence à família; e) o patrimônio e os ativos são objetos de transferência intergeneracional no interior da família; f) os membros da família vivem na unidade produtiva.

A agricultura familiar é responsável por grande parte da produção de alimentos no Brasil, e apresenta produção diversificada, denominada pluriatividade. O seu produto é destinado ao abastecimento da propriedade, e o excedente é vendido com vistas à obtenção de renda monetária (FUNK; BORGES; SALAMONI, 2006). A agricultura familiar tem sua base econômica marcada pela força de trabalho (SILVA, 2003) ligada aos recursos naturais disponíveis, com uma produção variada voltada para o consumo, e o excedente, para o mercado (TESTA et al., 1996).

\section{Aplicação da metodologia de planejamento da propriedade rural}

A pesquisa possui uma abordagem metodológica qualitativa, e, quanto aos objetivos, caracteriza-se como pesquisa do tipo exploratória. Quanto aos meios de investigação, a pesquisa é do tipo bibliográfica e estudo de caso. O estudo foi realizado em duas etapas.

Na primeira parte do estudo, após uma revisão teórica em diversos autores sobre planejamento estratégico e sobre as principais metodologias de elaboração de planejamento estratégico, foi possível apresentar uma proposta com as etapas do processo de planejamento estratégico para pequenas propriedades de base familiar, a qual está apresentada na subseção 2.4.1 do capítulo da revisão teórica. Na segunda, tendo em vista validar a proposta teórica, foram coletados dados junto a uma pequena propriedade de base familiar, tendo em vista a implementação da proposta. Os resultados do estudo serão 
apresentados por meio de quadros, tabelas, contemplando estratégias, objetivos, metas e ações da propriedade que é objeto deste estudo.

Este item apresenta os resultados da aplicação prática da metodologia de planejamento estratégico em uma pequena propriedade de base familiar.

\subsection{Implementação da proposta de metodologia de planejamento da propriedade}

Na sequência, apresenta-se a implementação da proposta de metodologia de planejamento estratégico a ser utilizada em pequenas propriedades rurais de base familiar.

\section{Etapa 1 - Dados gerais da propriedade}

A propriedade objeto deste estudo pertence ao Sr. João dos Anzóis (nome fictício), e está localizada no distrito de Pinhalzinho Baixo, município de Liberato Salzano (RS). A propriedade conta com 19,33 ha, estando dividida em duas áreas: a área 1, que conta com 8,33 ha, e a área 2 com 11 ha.

\section{Etapa 2 - Diagnóstico da propriedade}

A propriedade, desde a sua aquisição no ano de 1985, vem desenvolvendo as mesmas atividades agrícolas, entre as quais estão as ligadas principalmente à produção de grãos (milho, soja, feijão, arroz de sequeiro), à vitivinicultura (uva, vinho e vinagre) e à plantação de eucalipto. Além das atividades próprias, a propriedade mantém uma área destinada ao arrendamento agrícola, na produção de grãos. Também se desenvolvem atividades secundárias, como o cultivo de hortaliças, mandioca, batata-doce, pipoca e amendoim; a criação de suínos, aves, gado de corte e peixes, que servem de subsistência e eventual comercialização do excedente. Além desses cultivos, a propriedade apresenta uma área permanente de preservação ambiental (mata nativa). De acordo com o proprietário, a razão da existência da propriedade é produzir alimentos saudáveis, tendo em vista a qualidade de vida dos membros da família, com retorno econômico, sem causar impactos e danos ambientais. 
A propriedade quer ser reconhecida entre os municípios próximos como uma propriedade-modelo em produção de alimentos saudáveis e qualidade de vida. Para o proprietário, o desenvolvimento das atividades deve ser realizado observando os seguintes princípios: honestidade: busca-se a realização das tarefas com dignidade e procura-se passar esses valores adiante. Seriedade no processo: todas as atividades devem ser realizadas com seriedade para que se tenha um bom resultado final e um produto de qualidade. Persistência: diante dos problemas, não se deve desistir, mas buscar um novo caminho para vencer os obstáculos, persistindo até dar tudo certo. Entusiasmo: apesar das dificuldades, não perder a alegria e o amor por aquilo que se faz, pois, assim, o trabalho se torna mais prazeroso. Todos esses valores são de muita relevância em relação à condução das atividades, e, por outro lado, oferecem qualidade e confiabilidade a quem adquire esses produtos.

Dados produtivos da propriedade e seu uso

O relevo da propriedade caracteriza-se como de suavemente ondulado a ondulado, e a totalidade de sua área agrícola utilizável é mecanicamente agricultável. Os 19,33 ha são divididos em duas áreas. A área 1 é constituída de um Latossolo Vermelho Aluminoférrico típico, e a área 2 possui um Latossolo Vermelho Distrófico Húmico (EMBRAPA, 2006). A área 1 está distante $4 \mathrm{~km}$ da área 2, e ambas as áreas possuem sede com infraestrutura.

A área 1 é formada por 8,33 ha, estando assim distribuídos: 0,49 ha destinados às parreiras; 0,58 ha ao plantio de eucalipto; 2,79 ha, que são mecanicamente agricultáveis, destinados ao arrendamento agrícola; 0,5 ha de mata nativa; 1,18 ha destinado ao cultivo de culturas de subsistência, além da existência no local de uma fonte de água para a dessedentação, e o restante $(0,4$ ha) lugar de instalação da sede da propriedade. 0 quadro 2 apresenta as características da área 1 da propriedade.

Por meio do quadro, apresentam-se as áreas 1 e 2, esta última constituída de 11 ha, estando distribuídos da seguinte forma: 8,5 ha destinados ao arrendamento e com boa aptidão agrícola, possuindo uma nascente para consumo animal e uso para agricultura, sendo que no restante da área $(0,2$ ha) há dois açudes para piscicultura, além de três 
nascentes de água (uma nascente drenada, com água potável para consumo humano, e as demais para consumo animal), um potreiro e uma segunda sede da propriedade rural. 


\begin{tabular}{|c|c|c|c|c|c|c|c|c|c|c|c|c|c|c|}
\hline \multicolumn{7}{|c|}{ ÁREA 1} & & \multicolumn{7}{|c|}{ ÁREA 2} \\
\hline $\begin{array}{c}\text { Caracterís } \\
\text { ticas }\end{array}$ & Parreira & Eucalipto & $\begin{array}{c}\text { Arrendam } \\
\text { ento }\end{array}$ & $\begin{array}{l}\text { Subsis tên } \\
\text { cia } \\
\text { Culturas } \\
\text { Secundári } \\
\text { as }\end{array}$ & $\begin{array}{l}\text { Mata } \\
\text { Nativa }\end{array}$ & Potreiro & $\begin{array}{c}\text { Sede da } \\
\text { Proprieda } \\
\text { de }\end{array}$ & $\begin{array}{c}\text { Caracterís } \\
\text { ticas }\end{array}$ & $\begin{array}{c}\text { Arrendam } \\
\text { ento }\end{array}$ & Potreiro & $\begin{array}{c}\text { Mata } \\
\text { preservada }\end{array}$ & \begin{tabular}{|c|} 
Subsistên \\
cia \\
Culturas \\
Secundári \\
as
\end{tabular} & Açúdes & $\begin{array}{c}\text { Sede da } \\
\text { Proprieda } \\
\text { de }\end{array}$ \\
\hline Área (ha) & 0,49 & 0,58 & 2,79 & 1,18 & 1,89 & 1,10 & 0,30 & Área (ha) & 8,50 & 1,0 & 0,20 & 0,82 & 0,20 & 0,28 \\
\hline Solo & Latossolo & Latos solo & Latos solo & Latoss solo & Latossolo & Latossolo & Latossolo & Solo & Latos solo & Latos solo & Latossolo & Latos solo & Latos solo & Latos solo \\
\hline \begin{tabular}{|l|}
$\begin{array}{l}\text { Declive } \\
(\%)\end{array}$ \\
\end{tabular} & 8,12 & 11,38 & 7,0 & 10,83 & 7,63 & 14,46 & 15,73 & \begin{tabular}{|l|} 
Declive \\
$(\%)$
\end{tabular} & 6,0 & 10,0 & 11,95 & 11,0 & 10,0 & 11,0 \\
\hline Textura & Argilosa & Argilosa & Argilosa & Argilosa & Argilosa & Argilosa & Argilosa & Textura & Argilosa & Argilosa & Argilosa & Argilosa & Argilosa & Argilosa \\
\hline Drenagem & Boa & Média & Boa & Média & Boa & Regular & Boa & Drenagem & Boa & Boa & Boa & Boa & Boa & Boa \\
\hline \begin{tabular}{|l|} 
Risco de \\
inundação
\end{tabular} & Não & Não & Média & Não & Não & Sim & Não & \begin{tabular}{|l|} 
Risco de \\
inundação
\end{tabular} & Não & Não & Não & Não & Não & Não \\
\hline \begin{tabular}{|l|} 
Profundid \\
ade
\end{tabular} & Profundo & Profundo & Profundo & Profundo & Profundo & Regular & Profundo & \begin{tabular}{|l} 
Profundid \\
ade \\
\end{tabular} & Profundo & Profundo & Profundo & Profundo & Profundo & Profundo \\
\hline Erosão & Não & Sim & Não & Sim & Não & Sim & Não & Erosão & Não & Não & Não & Não & Não & Não \\
\hline \begin{tabular}{|l|}
$\begin{array}{l}\text { Pedregosi } \\
\text { dade }\end{array}$ \\
\end{tabular} & Média & Sim & \begin{tabular}{|c|}
$\begin{array}{c}\text { Não } \\
\text { pedregoso }\end{array}$ \\
\end{tabular} & Sim & Regular & Sim & Não & $\begin{array}{l}\text { Pedregosi } \\
\text { dade }\end{array}$ & \begin{tabular}{|c|} 
Não \\
pedregoso
\end{tabular} & \begin{tabular}{|c|} 
Não \\
pedregoso
\end{tabular} & $\begin{array}{c}\text { Não } \\
\text { pedregoso }\end{array}$ & \begin{tabular}{|c|} 
Não \\
pedregoso
\end{tabular} & \begin{tabular}{|c|} 
Não \\
pedregoso
\end{tabular} & $\begin{array}{c}\text { Não } \\
\text { pedregoso }\end{array}$ \\
\hline
\end{tabular}

Fonte: Dados da pesquisa.

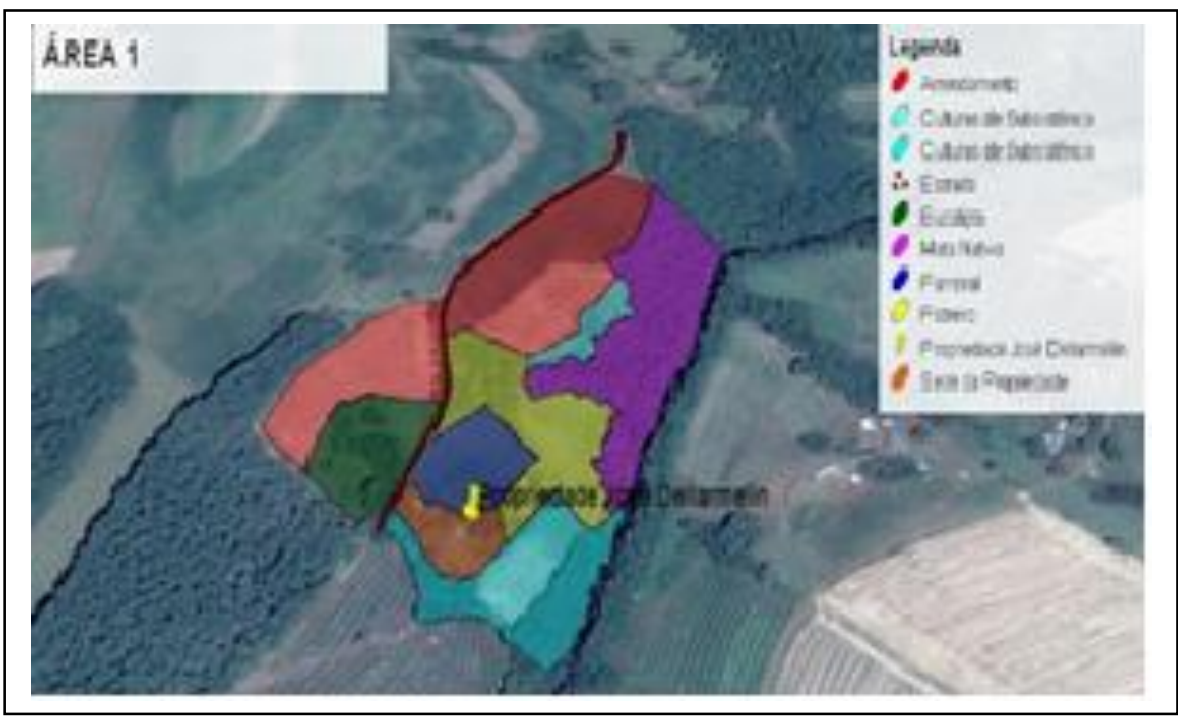

Fonte: Dados da pesquisa.

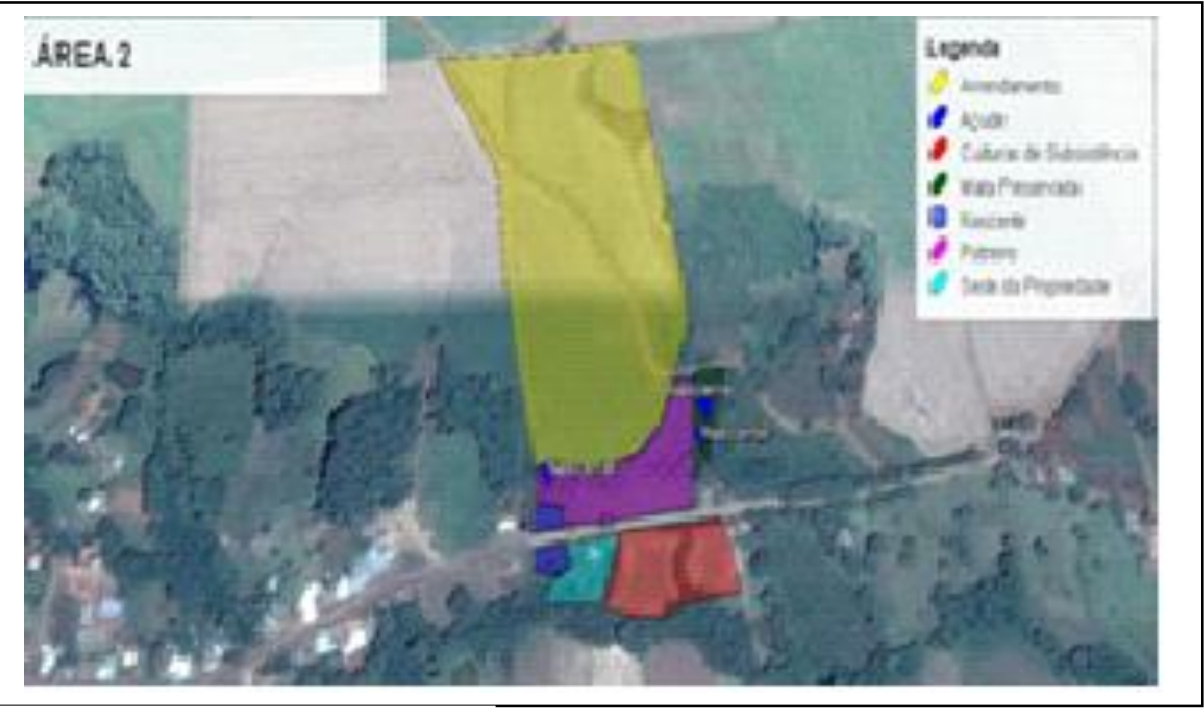

Fonte: Dados da pesquisa. 
O acesso à área 1 não se encontra em boas condições, dificultando o escoamento da produção. Já na área 2, as condições de acesso estão em melhores condições. Em ambas as áreas, a propriedade conta com rede de energia elétrica e de abastecimento de água para o consumo humano, sendo essa água oriunda do sistema público. Existe também acesso à telefonia através do sinal 3G; a rede de energia elétrica é de média tensão. Na época de instalação da energia elétrica, todos os beneficiados tiveram que pagar todos os custos para a sua implantação.

A propriedade conta com infraestrutura em bom estado de conservação na área 1 , como instalações de madeira (casa, chiqueiro, galpões, garagem e um galpão menor feito de depósito), além de arames e cercas elétricas. Na área 2, a infraestrutura é menor, contando com uma casa de alvenaria, apenas um galpão de madeira e uma cerca de arame farpado.

Análise dos aspectos econômicos e financeiros

O quadro 4, apresentam-se os valores dos bens, direitos e obrigações que integram o patrimônio da propriedade, objeto do estudo. Os valores dos bens e direitos foram obtidos junto ao proprietário, considerando o valor de mercado de 31/12/2015. 
Quadro 4 - Levantamento dos valores do patrimônio da propriedade em 31/12/2015

\begin{tabular}{|c|c|}
\hline ATIVO & $\mathbf{R} \$$ \\
\hline \multicolumn{2}{|l|}{ Ativo Circulante } \\
\hline Dinheiro em caixa & 500,00 \\
\hline Dinheiro em bancos & $20.000,00$ \\
\hline A receber arrendamento & $20.000,00$ \\
\hline Produtos e materiais em estoque - Vinho & $25.000,00$ \\
\hline Estoque - Vinagre & 600,00 \\
\hline Estoque - Grãos & $4.500,00$ \\
\hline Sub total & $70.600,00$ \\
\hline \multicolumn{2}{|l|}{ Ativo Não Circulante } \\
\hline Terras & $255.000,00$ \\
\hline Veículo & $15.000,00$ \\
\hline Parreiras & $25.000,00$ \\
\hline Benfeitorias & $76.000,00$ \\
\hline Máquinas e equipamentos & $2.900,00$ \\
\hline Animais de produção & $5.000,00$ \\
\hline Sub total & $378.900,00$ \\
\hline TOTAL DO ATIVO & $449.500,00$ \\
\hline PASSIVO & - \\
\hline \multicolumn{2}{|l|}{ Passivo Circulante } \\
\hline \multicolumn{2}{|l|}{ - Títulos e contas a pagar } \\
\hline \multicolumn{2}{|l|}{ - Impostos devidos } \\
\hline \multicolumn{2}{|l|}{ - Salários a pagar } \\
\hline \multicolumn{2}{|l|}{ - Empréstimos a pagar } \\
\hline \multicolumn{2}{|l|}{ - Outros } \\
\hline Total do Passivo & \\
\hline
\end{tabular}

Fonte: Dados da pesquisa

Descrição dos componentes do patrimônio da propriedade:

Dinheiro em caixa: trata-se dos recursos financeiros em caixa na propriedade.

Dinheiro em bancos: representa os recursos financeiros depositados na conta poupança da família.

A Receber-Arrendamento: refere-se ao valor a receber do arrendamento anualmente. 
Produtos e materiais em estoque: é o valor de venda a receber dos produtos em estoque (vinho, vinagre e grãos).

Terras: valor referente às terras das áreas 1 e 2, sendo que a área 1 conta com 8,33 ha e a área 2 possui 11 ha.

Veículo: indica o valor de mercado do automóvel da família (Corcel I GT, ano 1975).

Parreiras: referente ao valor gasto para na sua construção.

Benfeitorias: relacionada ao valor de venda da benfeitoria nas áreas 1 e 2.

Máquinas e equipamentos: valor referente às máquinas e equipamentos utilizados nas áreas 1 e 2 (roçadeira costal, pulverizador costal, motor para triturar grãos, motobomba para bombear água, carrinho de mão).

Animais de produção: representa o valor da venda dos animais na área 1.

O quadro 5 apresenta o resultado econômico relativo ao exercício de 2015 da propriedade. Os valores obtidos foram apurados por meio de entrevista com o proprietário. 


\section{Quadro 5 - Demonstração do resultado do exercício de 2015}

\begin{tabular}{|c|c|c|c|}
\hline \multicolumn{3}{|c|}{ Receitas com vendas } & Ano de 2015 \\
\hline & \multicolumn{2}{|c|}{ Venda de Uva (granel) } & $2.000,00$ \\
\hline & \multicolumn{2}{|c|}{ Venda de Vinho } & $8.200,00$ \\
\hline & \multicolumn{2}{|c|}{ Venda de Vinagre } & 350,00 \\
\hline SOMA & & & $10.550,00$ \\
\hline \multicolumn{3}{|c|}{ Custo de Produção da UVA } & $5.600,00$ \\
\hline \multicolumn{3}{|c|}{ Lucro Bruto } & $4.950,00$ \\
\hline \multicolumn{3}{|c|}{ Arrendamento Mercantil } & $20.000,00$ \\
\hline \multicolumn{3}{|c|}{ Lucro Bruto com o Arrendamento } & $24.950,00$ \\
\hline & \multicolumn{3}{|c|}{ Despesas Operacionais } \\
\hline & & Despesas com Telefone & 240,00 \\
\hline & & Despesas com Luz & $1.176,36$ \\
\hline & & Despesas comágua & 144,00 \\
\hline & & Despesas com supermercado & $2.940,00$ \\
\hline & & Despesas com Farmácia/plano de saúde/médicos & 588,80 \\
\hline & & Despesas com combustíveis & $2.880,00$ \\
\hline & & Despesas com Manutenção de máquinas e equipamentos & 600,00 \\
\hline & & Despesaas com manutenção de veículos & $1.320,00$ \\
\hline & & Despesas com associações/cooperativas/sindicatos & 105,00 \\
\hline & & Despesas com ITR & 40,00 \\
\hline & & Despesas com filhos & $3.120,00$ \\
\hline & & Material escolar & 100,00 \\
\hline & & Despesas diversas & 800,00 \\
\hline \multicolumn{3}{|c|}{ SOMA DAS DESPESAS } & $14.054,16$ \\
\hline \multicolumn{3}{|c|}{ Lucro Operacional } & $10.895,84$ \\
\hline & \multicolumn{2}{|c|}{ Venda de Gado } & $3.000,00$ \\
\hline & \multirow{2}{*}{\multicolumn{2}{|c|}{$\begin{array}{l}\text { Outras Receitas } \\
\text { DO EXERCÍCIO }\end{array}$}} & $1.200,00$ \\
\hline LUCRO & & & $15.095,84$ \\
\hline
\end{tabular}

Fonte: Dados da pesquisa.

O proprietário mantém controle dos valores das receitas, custos e despesas em anotações realizadas em cadernos e fichas. No ano de 2015, a principal receita obtida na propriedade relaciona-se ao arrendamento mercantil, representando um retorno de 180 sacas de milho por ano, num valor de $\mathrm{R} \$ 20.000,00$. Além do arrendamento, no ano de 2015 , a vitivinicultura (venda de uva, vinho e vinagre) foi a segunda principal atividade geradora de renda desenvolvida na propriedade, no valor de $\mathrm{R} \$ 10.550,00$.

Os gastos com custos de produção, relativos à produção de uva, foram de R\$ $5.600,00$. No que se refere aos gastos com despesas operacionais, estas estão relacionadas primordialmente ao sustento da família, sendo que, no ano de 2015 , o valor dos gastos foi de $\mathrm{R} \$ 14.054,16$. O resultado das atividades operacionais desenvolvidas na propriedade, no ano de 2015 , foi de $R \$ 10.895,84$, os quais, com o acréscimo das receitas com a venda de 
gado e outras receitas, perfazem o montante de $\mathrm{R} \$ 1$ 15.095,84. A comercialização dos produtos oriundos da propriedade rural é realizada no município de Liberato Salzano (RS), e municípios próximos.

No que diz respeito à safra de uva, uma parte da sua produção é comercializada no próprio município $(2000 \mathrm{~kg})$ e o restante $(4.500 \mathrm{~kg})$ destina-se à produção de vinho e vinagre na propriedade. A concorrência de outros produtores do município praticamente não influencia na comercialização da produção gerada na propriedade.

Gestão de pessoas

A propriedade é constituída de três membros, sendo eles o proprietário, sua esposa e sua filha, que é estudante do Curso de Agronomia e auxilia nas atividades da casa nos finais de semana. A sucessão familiar será realizada pela filha do casal, após a conclusão do curso superior em Agronomia.

As atividades na propriedade são desempenhadas conjuntamente, não havendo responsabilidades e atribuições de cada membro da família em atividades específicas. Os proprietários são encarregados de cuidar da vitivinicultura e demais culturas. Em períodos de colheita, a propriedade conta com o auxílio da mão de obra de vizinhos, em especial na colheita da uva. Em contrapartida, os proprietários prestam auxílio nas colheitas em propriedades vizinhas. Os serviços (limpeza, roçadas, aplicação de insumos, fertilizantes, etc.) são realizados no andamento das culturas e ocorrem de forma manual, não havendo mecanização nesses processos.

Análise do ambiente interno e externo (da porteira para dentro e da porteira para fora)

Nesta etapa, buscou-se descrever, por meio da matriz SWOT, os pontos fortes e fracos em relação ao ambiente interno da propriedade, e as ameaças e oportunidades em relação ao ambiente externo da propriedade rural. O quadro 6 apresenta os pontos fortes e fracos, as oportunidades e ameaças em relação à pequena propriedade. 


\section{Quadro 6 - Matriz SWOT - Análise do ambiente interno e externo da propriedade}

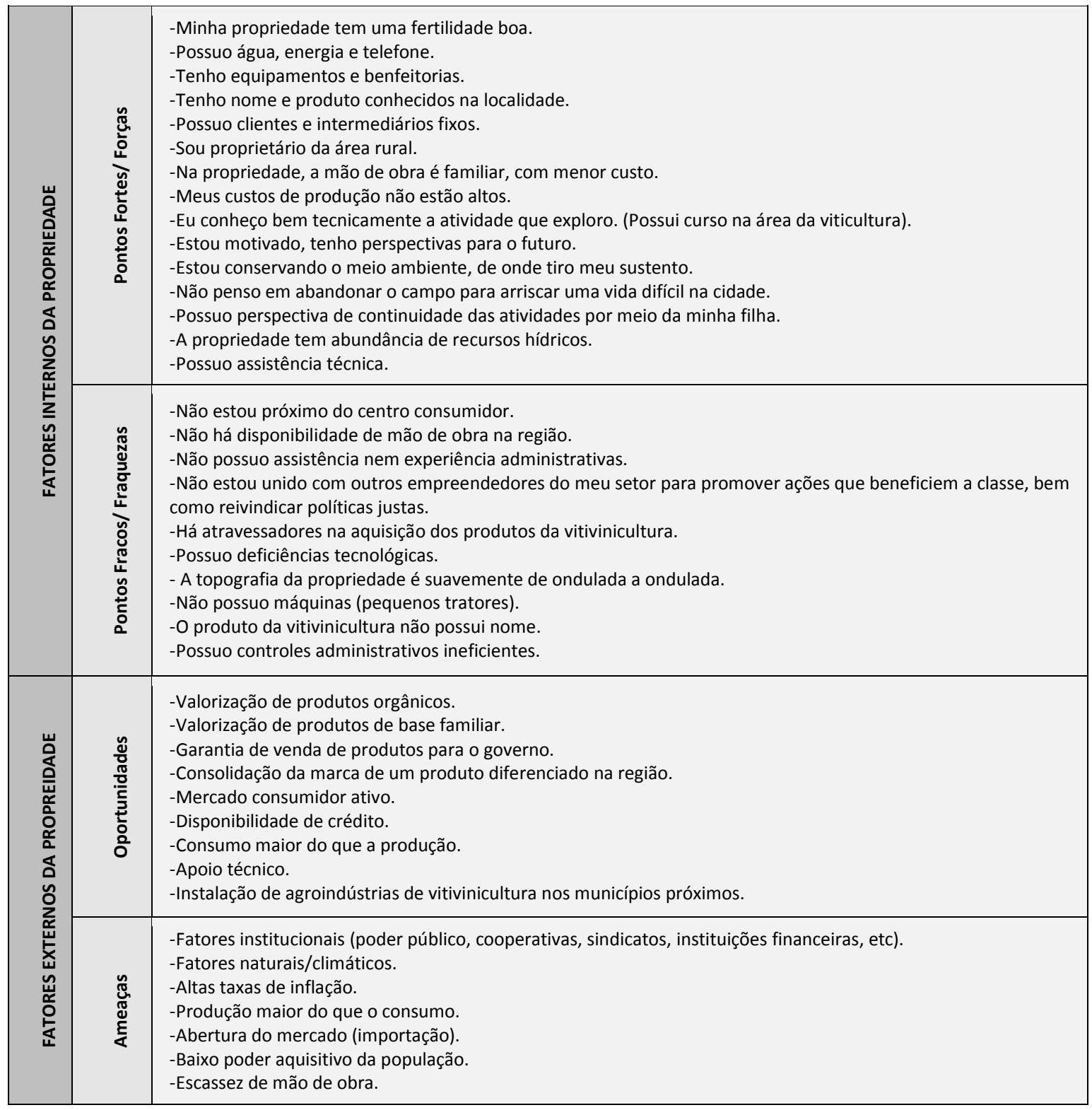

Fonte: Dados da pesquisa.

A identificação dos pontos fortes e fracos, das oportunidade e ameaças, foi possível graças à entrevista com o dono da propriedade e sua família, quando foram definidas as estratégias que estão descritas na próxima etapa.

\section{Etapa 3 - Formulação de estratégias e objetivos (Onde queremos chegar?)}

As principais estratégias em uma pequena propriedade rural são as seguintes: a) ampliar ou diminuir a área para o cultivo agrícola; b) renovar equipamentos, mediante 
financiamentos ou não; c) aumentar atividades agrosilvipastoris; d) modificar as atividades de produção realizadas.

Os objetivos decorrem da formulação das estratégias, por meio das quais, de acordo com o proprietário, em linhas gerais, a propriedade visa, como prioridade, dar continuidade às atividades que já estão sendo realizadas, como fica representado no quadro 7.

Quadro 7 - Formulação de estratégias e objetivos da propriedade

\begin{tabular}{|l|c|c|c|c|}
\hline \multicolumn{1}{|c|}{ Estratégias } & Objetivo & Início & Fim & $\begin{array}{c}\text { Custo } \\
\text { Aproximado }\end{array}$ \\
\hline Aumento de área com parreiras & 1 & 2016 & 2017 & $10.000,00$ \\
\hline Aquisição de micro trator com pulverizador & 2 & 2016 & 2017 & $16.000,00$ \\
\hline Cobertura/proteção dos parreirais existentes (0,49 ha) & 3 & 2016 & 2019 & $15.000,00$ \\
\hline Início das atividades com a piscicultura & 4 & 2016 & 2017 & $8.000,00$ \\
\hline Associação com outros produtores de uva & 5 & 2016 & 2017 & ----- ----- $^{-}$ \\
\hline
\end{tabular}

Fonte: Dados da pesquisa.

Descrição dos objetivos

1 - Aumentar a área da cultura de uva em 0,50 hectare, possibilitando um aumento na produção de $5.000 \mathrm{~kg}$ de uva e, consequentemente, acréscimo na renda.

2 - Adquirir um micro trator com pulverizador, visando facilitar o trabalho que até então é realizado manualmente.

3 - Providenciar a cobertura do parreiral, tendo em vista diminuir gastos com defensivos e minimizar o ataque de pragas, alcançando, consequentemente, uma maior produtividade.

4 - Iniciar as atividades da piscicultura, por meio da abertura de dois tanques de 0,10 ha, para o consumo do alimento na propriedade e comercialização local ou nas vendas governamentais.

5 - Organizar com outros produtores de uva uma associação para maior visibilidade dos produtos e seus derivados e para a obtenção de melhores preços nos produtos. 
Etapa 4 - Definição das metas

Uma meta pode ser definida como a quantificação dos objetivos e o seu prazo de realização. Por meio dos quadros apresentados na etapa 6 , serão definidas as metas em relação aos objetivos propostos.

\section{Etapa 5 - Projeções financeiras}

Após a definição das estratégias, objetivos e metas, será possível apresentar as projeções de balanço patrimonial e dos resultados das atividades da propriedade, bem como os fluxos de caixa, com a integração dos valores decorrentes das metas a serem atingidas.

Projeção dos resultados

O quadro 8 apresenta os resultados projetados até o ano de 2020. 
Quadro 8 - Projeções de resultados da propriedade

\begin{tabular}{|c|c|c|c|c|c|c|}
\hline Receitas com vendas & $31 / 12 / 2015$ & $31 / 12 / 2016$ & $31 / 12 / 2017$ & $31 / 12 / 2018$ & $31 / 12 / 2019$ & $31 / 12 / 2020$ \\
\hline Venda de Uva (granel) & $2.000,00$ & $1.500,10$ & $1.714,40$ & $1.714,40$ & $2.143,00$ & $2.143,00$ \\
\hline Venda de Vinho & $8.200,00$ & $23.998,80$ & $27.427,20$ & $27.427,20$ & $34.284,00$ & $34.284,00$ \\
\hline Venda de Vinagre & 350,00 & 700,00 & $1.050,00$ & $1.050,00$ & $1.400,00$ & $1.400,00$ \\
\hline SOMA & $10.550,00$ & $26.198,90$ & $30.191,60$ & $30.191,60$ & $37.827,00$ & $37.827,00$ \\
\hline Custo de Produção da UVA & $5.600,00$ & $5.600,00$ & $5.600,00$ & $5.600,00$ & $5.600,00$ & $5.600,00$ \\
\hline Lucro Bruto & $4.950,00$ & $20.598,90$ & $24.591,60$ & $24.591,60$ & $32.227,00$ & $32.227,00$ \\
\hline Arrendamento Mercantil & $20.000,00$ & $20.000,00$ & $20.000,00$ & $20.000,00$ & $20.000,00$ & $20.000,00$ \\
\hline Lucro Bruto com o Arrendamento & $24.950,00$ & $40.598,90$ & $44.591,60$ & $44.591,60$ & $52.227,00$ & $52.227,00$ \\
\hline \multicolumn{7}{|l|}{ Despesas Operacionais } \\
\hline Despesas com Telefone & 240,00 & 240,00 & 240,00 & 240,00 & 240,00 & 240,00 \\
\hline Despesas com Luz & $1.176,36$ & $1.500,00$ & $1.800,00$ & $2.000,00$ & $2.000,00$ & $2.000,00$ \\
\hline Despesas com água & 144,00 & 150,00 & 150,00 & 150,00 & 150,00 & 150,00 \\
\hline Despesas com supermercado & $2.940,00$ & $3.000,00$ & $3.200,00$ & $3.500,00$ & $3.800,00$ & $4.000,00$ \\
\hline Despesas com Farmácia/plano de & 588,80 & 600,00 & 650,00 & 700,00 & 800,00 & 850,00 \\
\hline Despesas com combustíveis & $2.880,00$ & $3.000,00$ & $3.500,00$ & $3.500,00$ & $3.600,00$ & $3.700,00$ \\
\hline Despesas com Manutenção de má & 600,00 & & & & & \\
\hline Despesaas com manutenção de ve & $1.320,00$ & $1.320,00$ & $1.320,00$ & $1.320,00$ & $1.320,00$ & $1.320,00$ \\
\hline Despesas com associações/coopeı & 105,00 & & & & & \\
\hline Despesas com ITR & 40,00 & 50,00 & 60,00 & 70,00 & 80,00 & 90,00 \\
\hline Despesas com filhos & $3.120,00$ & $3.000,00$ & $3.000,00$ & $3.000,00$ & $3.000,00$ & $3.000,00$ \\
\hline Material escolar & 100,00 & & & & & \\
\hline Despesas diversas & 800,00 & $1.000,00$ & $1.000,00$ & $1.000,00$ & $1.000,00$ & $1.000,00$ \\
\hline SOMA DAS DESPESAS & $14.054,16$ & $13.860,00$ & $14.920,00$ & $15.480,00$ & $15.990,00$ & $16.350,00$ \\
\hline Lucro Operacional & $10.895,84$ & $26.738,90$ & $29.671,60$ & $29.111,60$ & $36.237,00$ & $35.877,00$ \\
\hline Venda de Gado & $3.000,00$ & & & & & \\
\hline Outras Receitas & $1.200,00$ & & & & & \\
\hline LUCRO DO EXERCÍCIO & $15.095,84$ & $26.738,90$ & $29.671,60$ & $29.111,60$ & $36.237,00$ & $35.877,00$ \\
\hline
\end{tabular}

Fonte: Dados da pesquisa.

\section{Etapa 6 - Implementação das ações}

Por meio de planos de ações, que podem ser de responsabilidade de cada membro da família, será possível a implementação das ações operacionais do planejamento. Nessa perspectiva, cada estratégia com o(s) objetivo(s) e ações com as metas podem ser implementadas. 
Estratégias, objetivos, plano de ações e cronograma

O plano de ação, representado por meio do quadro 9, apresenta o primeiro objetivo, que está ligado à estratégia de aumentar a área da produção de uva, elevando a produtividade e, consequentemente, o aumento da renda.

Quadro 9 - Plano de ação, estratégia, objetivo e cronograma

\begin{tabular}{|l|l|}
\hline \multicolumn{2}{|c|}{ Plano de Ação } \\
\hline Estratégia: & Aumento da área de parreiras \\
\hline Objetivo: & 1 \\
\hline Por quê: & Aumento da produtividade e, consequentemente, o aumento de renda \\
\hline Como fazer: & Através de enxertos das mudas, colocação de palanques e de arames. \\
\hline Quem (Responsável): & Proprietário \\
\hline Quando (Prazo): & Início: 2016 \\
\hline Quanto (custo estimado) R\$: & $10.000,00$ \\
\hline
\end{tabular}

Fonte: Dados da pesquisa.

No que diz respeito ao segundo objetivo do plano de ações da propriedade, conforme demonstrado no quadro 10 , este consiste na compra do pulverizador acoplado ao micro trator, para facilitar, assim, a realização das atividades agrícolas.

\section{Quadro 10 - Plano de ação, estratégia, objetivo e cronograma}

\begin{tabular}{|l|l|}
\hline \multicolumn{2}{|c|}{ Plano de Ação } \\
\hline Estratégia: & Aquisição de micro trator com pulverizador \\
\hline Objetivo: & 2 \\
\hline Por quê: & Facilitar o trabalho nas parreiras. \\
\hline Como fazer: & Aquisição através de recursos próprios. \\
\hline Quem (Responsável): & Proprietário \\
\hline Quando (Prazo): & Início: 2016 \\
\hline Quanto (custo estimado) R\$: & $16.000,00$ \\
\hline
\end{tabular}

Fonte: Dados da pesquisa.

O quadro 11 apresenta o terceiro objetivo, com a estratégia de cobertura/proteção dos parreirais já existentes na propriedade, com o intuito de reduzir o uso de defensivos agrícolas, minimizar o ataque de pragas e doenças, além da ação do clima. 
Quadro 11 - Plano de ação, estratégia, objetivo e cronograma

\begin{tabular}{|l|l|l|}
\hline \multicolumn{2}{|c|}{ Plano de Ação } \\
\hline Estratégia: & Cobertura/proteção dos parreirais existentes (0,49 ha). \\
\hline Objetivo: & 3 & \\
\hline Por quê: & $\begin{array}{l}\text { Diminuir o uso de defensivos, minimizando o ataque de pragas e as } \\
\text { perdas através das intempéries climáticas. }\end{array}$ \\
\hline Como fazer: & Através de recursos próprios. \\
\hline Quem (Responsável): & Proprietário & Fim: 2019 \\
\hline Quando (Prazo): & Início: 2016 & \\
\hline Quanto (custo estimado) R\$̦: & R\$ 15.000,00 \\
\hline
\end{tabular}

Fonte: Dados da pesquisa.

O quadro 12 demonstra o quarto objetivo, relacionando-o à respectiva estratégia, envolvendo o início das atividades da piscicultura, primeiramente para consumo da família, e o excedente podendo ser comercializado nos locais vizinhos.

\section{Quadro 12 - Plano de ação, estratégia, objetivo e cronograma}

\begin{tabular}{|l|l|}
\hline \multicolumn{2}{|c|}{ Plano de Ação } \\
\hline Estratégia: & Início das atividades da piscicultura \\
\hline Objetivo: & 4 \\
\hline Por quê: & Para o complemento da renda da propriedade e consumo da família. \\
\hline Como fazer: & Através de recursos próprios e com auxílio da Prefeitura Municipal. \\
\hline Quem (Responsável): & Proprietário e Prefeitura Municipal \\
\hline Quando (Prazo): & Início: 2016 \\
\hline Quanto (custo estimado) R\$: & R\$ 8.000,00 \\
\hline
\end{tabular}

Fonte: Dados da pesquisa.

O quadro 13 mostra o quinto objetivo do plano de ação, com a estratégia de criação de uma associação com os demais produtores de uva do município de Liberato Salzano/RS, e, assim, aproximá-los, garantindo a visibilidade do produto e de preços mínimos na sua comercialização. 
Quadro 13 - Plano de ação, estratégia, objetivo e cronograma

\begin{tabular}{|c|c|c|}
\hline \multicolumn{3}{|c|}{ Plano de Ação } \\
\hline Estratégia: & \multicolumn{2}{|c|}{ Associação com outros produtores de uva } \\
\hline Objetivo: & \multicolumn{2}{|l|}{5} \\
\hline Por quê: & \multicolumn{2}{|c|}{$\begin{array}{l}\text { Para aproximar os produtores, garantindo a visibilidade do produto e de } \\
\text { preços mínimos de venda. }\end{array}$} \\
\hline Como fazer: & \multicolumn{2}{|c|}{ Através de encontros e reuniões de formação } \\
\hline Quem (Responsável): & \multicolumn{2}{|l|}{ Emater } \\
\hline Quando (Prazo): & Início: 2016 & Fim: 2017 \\
\hline Quanto (custo estimado) R\$: & \multicolumn{2}{|l|}{--------- } \\
\hline
\end{tabular}

Fonte: Dados da pesquisa.

\section{Etapa 7 - Avaliação e controle}

Após a elaboração dos planos de ações, são necessários a avaliação e o controle, tendo em vista verificar os níveis de eficiência e eficácia das estratégias. O controle e monitoramento dos planos devem ser realizados, para, prontamente, as ações corretivas, se forem necessárias, ocorrerem de forma a garantir o resultado esperado.

\section{Considerações finais}

O planejamento estratégico pode ser definido como um processo de gestão que proporciona estabelecer o aspecto futuro das decisões institucionais, a partir da formulação de seus objetivos, metas, programas e estratégias a serem empregados para assegurar sua execução.

Os resultados demonstram a importância de um planejamento estratégico na propriedade rural, para que as condições em que se encontram possam ser avaliadas, e o seu futuro planejado. Com a aprovação da metodologia junto a uma propriedade, pode conhecerse os seus dados produtivos, a composição familiar, os aspectos econômicos e financeiros e o ambiente interno e externo dessa propriedade. A propriedade em estudo possui rendas oriundas das atividades de vitivinicultura e do arrendamento agrícola. Quanto aos aspectos financeiros, verificou-se que a propriedade desenvolve suas atividades com recursos próprios.

Após o diagnóstico da propriedade, foi possível a formulação de estratégias e objetivos a serem ali executadas até o ano de 2020. Nessa perspectiva, o planejamento visa 
direcionar a propriedade, tendo em vista alcançar o seu melhor desempenho. Novos estudos podem ser realizados mediante a aplicação da presente metodologia junto a outras pequenas propriedades.

\section{Referências}

ABRAMOVAY, R. Agricultura Familiar e uso do solo. Disponível em:

<abramovay.pro.br/artigos/1997/Agricultura_familiar.pdf>. Acesso em: 26 jul. 2010.

ALMEIDA, M. I. R. Manual de planejamento estratégico. São Paulo: Atlas, 2001.

AMARAL, D. C. et al. Gerenciamento Ágil de Projetos: aplicação em produtos inovadores. São Paulo: Saraiva, 2010.

ANTUNES, L.M.; ENGEL, A. Manual de administração rural: custos de produção. 3. ed. Guaíba: Agropecuária. 1999.

BRASIL. Lei no 4.504, de 30 de novembro de 1964. Dispõe sobre o Estatuto da Terra e dá outras providências. Disponível em: <http://www.planalto.gov.br/ccivil_03/ leis/L4504compilada.htm>. Acesso em: 19 jun. 2016.

BRUN, R. Planejamento Estratégico Aplicado a uma Propriedade Rural de Atividade Leiteira. (Monografia Final de Curso) - Faculdade de Horizontina, Horizontina, 2013.

CALLADO, A. L. C.; ALBUQUERQUE, J. de L.; SILVA, M. N. Análise da Relação Custo/Volume/Lucro na Agricultura Familiar: o caso do Consórcio Mamona/Feijão. Custos e @gronegócio on line, v. 3, n. 1, jan. jun. 2007.

CERTO, S. C.; PETER, J. P. Administração estratégica: planejamento e implantação da estratégia. São Paulo: Makron Books, 1993.

CHIAVENATO, I. Administração: teoria, processo e prática. 2. ed. São Paulo: Makron Books, 1994.

DAFT, R. L. Administração. Rio de Janeiro: LTC. 1999.

EMBRAPA, Sistema Brasileiro de Classificação de Solos. 2. ed. Rio de Janeiro: Embrapa solos, 2006. 
FUNK, F.; BORGES, M. A.; SALAMONI, G. Pluriatividade: uma estratégia de sustentabilidade na agricultura familiar nas localidades de Capão Seco e Barra Falsa 3을 Distrito - Rio Grande (RS). Geografia - v. 15, n. 2, jul./dez. 2006.

JANK, M. S.; LOPES, M. R. O setor leiteiro, a intervenção do Estado e o MERCOSUL: análise e propostas de estratégias e políticas. São Paulo: ABPLB, 1992.

NEVES, M. F. A busca do comprometimento organizacional para o processo de planejamento estratégico. In: Anais do I SEMEAD, São Paulo, FEA/USP, p. 12- 32, outubro/1996.

RIBEIRO, E. M. Sistemas do Pica Pau - Sociedade Camponesa e Organização da Produção na Zona da Mata Mineira. In: II Encontro da Sociedade Brasileira de Sistemas de Produção, Londrina, 1995. p. 237-245.

SALDANHA, A. N. K.; SOARES JÚNIOR, D.; DEL GROSSI, M. E. Um modelo de planejamento estratégico adaptado às empresas familiares rurais. In: II Seminário Sul-Brasileiro de Administração Rural,2002, Passo Fundo/RS. Anais do II Seminário Sul-Brasileiro de Administração Rural. Universitária, 2002. v. 1, p. 293-305.

SANTOS, N. M. dos. Planejamento Estratégico: como foco na Gestão Hospitalar. VII Convibra Administração - Congresso Virtual Brasileiro de Administração. Disponível em:

<www.convibra.com.br>. Acesso em: 26 jul. 2010.

SILVA, P. A Agrodiversidade como Estratégia de Viabilização da Unidade de Produção Familiar no Município de Passo Fundo/RS. (Programa de Pós-Graduação em Desenvolvimento Regional - Mestrado e Doutorado) - Universidade de Santa Cruz do Sul, Santa Cruz do Sul, 2003.

TAJRA, S. F. Gestão Estratégica na Saúde: reflexões e práticas para uma administração voltada para a excelência. São Paulo: látria, 2006.

TERENCE, A. C. Planejamento estratégico na pequena empresa: as particularidades das pequenas empresas no processo estratégico. In: XXI Encontro Nacional de Engenharia de Produção. Anais, Salvador/BA, 2002.

TESTA, V. M. et al. O Desenvolvimento Sustentável do Oeste Catarinense. Florianópolis: EPAGRI, 1996.

THOMPSON JR., A. A.; STRICKLAND III, A. J. Planejamento Estratégico: elaboração, implementação e execução. São Paulo: Pioneira. 2000.

VILCKAS, M. Os Determinantes para a Tomada de Decisão sobre O que Produzir: proposta de um modelo para unidades de produção rural familiares. 2004. 143f. Dissertação (Mestrado em Engenharia de Produção) - Universidade Federal de São Carlos, São Carlos, 2004. 